\title{
Development of Pre-service Science Teachers' Understanding and Attitude towards Science Project by Teaching Management through Service Learning
}

\author{
Sasithep Pitiporntapin ${ }^{1} \&$ Tassaneewon Lertcharoenrit ${ }^{2}$ \\ ${ }^{1}$ Division of Science Education, Department of Education, Faculty of Education, Kasetsart University, Bangkok, \\ Thailand \\ ${ }^{2}$ Department of Science Learning at Kasetsart University Laboratory School Center for Educational Research \\ and Development, Thailand \\ Correspondence: Sasithep Pitiporntapin, Division of Science Education, Department of Education, Faculty of \\ Education, Kasetsart University, Bangkok, 10900 Thailand. Tel: 66(0)2579-7114 ext.161. E-mail: \\ fedustp@ku.ac.th
}

Received: November 28, 2016

Accepted: January 2, $2017 \quad$ Online Published: January 19, 2017

doi:10.5539/ass.v13n2p126

URL: http://dx.doi.org/10.5539/ass.v13n2p126

\begin{abstract}
The purposes of this research were to develop Pre-service Science Teachers' (PSTs) understanding and attitude towards science by teaching management through service learning. The participants of this study were 9 volunteer PSTs who enrolled in 15-week Science and Technology Project in School course in the universities in Bangkok. This course focused on PSTs' application of knowledge about science project to solve problem via doing community service. The researcher gathered data from observation, journal entries, and artifacts in the first semester of academic year 2015. Moreover, informal interviews were used for clarification. For data analysis, the researchers analyzed data with descriptive statistics and content analysis. Findings showed that most PSTs had increased understanding in doing a science project in aspects of integration to other learning disciplines, role of students, and role of advisors. Moreover, PSTs also increased their attitude towards a science project due to the construction of knowledge by themselves, development of many skills, and generation of societal benefits. These findings were considered in terms of further designing other courses activities.
\end{abstract}

Keywords: Pre-service science teachers, Science project, Service learning

\section{Introduction}

A science project is a teaching activity that enables learner education through doing research with the processes and knowledge of science in order to solve problems. Learners have freedom to construct their own knowledge by themselves. This is the main goal of doing research for knowledge. The role of teachers is to guide and give consultation to learners (Buck Institute for Education, 1999). In correspondence to learning in the $21^{\text {st }}$ century, the emphasis is for learners to gain meaningful learning and the ability to solve problems by themselves (Partnership for $21^{\text {st }}$ Century Skills, 2009). In addition, creating the end-product of project provides students' opportunities to develop their confidence and independence and to work together in a real- world environment (Blumenfeld et al., 1991) To support this idea, chapter 4 of the National Education Act B.E. 2542 (A.D. 1999) and Amendments (Second National Education Act B.E. 2545 (A.D. 2002) provides the guidelines of learning process focuses on a student-centered approach, in which students engage in activities based upon their interests and their individual differences (Office of the National Education Commission (ONEC), 2003). Therefore, the aims of science teaching and learning emphasize on linking knowledge with processes, acquiring essential skills for investigation, building knowledge through investigative processes, seeking knowledge and solving various problems. Learners are allowed to participate in all stages of learning, with activities organized through diverse practical work suitable to their levels (The Institute for the Promotion of Teaching Science and Technology (IPST), 2008).

Although science project has many advantages for learner, it also has several limitations in time consuming and recourses consumption. It also requires professional teachers who can set up the proper learning environment (Dosch, 1998). Consequently, the researchers, as teachers in "Science and Technology Project in School" course 
for five years, found that most PSTs understand that a science project is related only to science and technology not related much to social dimension. Typically, they accomplished a project according to their advisor's guidelines. However, they do not have a positive attitude toward a science project, for instance, they do not like to do research in a science project as they think it is a complicated process and not applicable to actual life conditions. To deal with these problems, the researchers have to find teaching management approach that could change students' attitudes to be positive or negative.

Service learning is one of the teaching management approaches that have flexible characteristics and enables learning to be integrated with other disciplines (Prentice \& Garcia, 2000). It differs from the traditional practice of sitting in the classroom studying books and waiting till school career has finished before encountering society. Students are prepared earlier to be part of their local community with a sense that their abilities are valuable (Lin et al., 2013). In effect, teaching management with an emphasis on service learning includes four points, namely, community participation, reflection on ideas, active learning, and relevant concern among stakeholders $\left(\mathrm{O}^{\prime}\right.$ Grady, 2000). PSTs who are learning through these teaching management gain direct experiences for their future professional teaching careers and also be able to develop their acquiring academic knowledge (Prentice \& Garcia, 2000).

Therefore, it is challenge that the researchers used service learning in the Science and Technology Project in School course for creating a community of learner that would get PSTs engaged in activities outside of class. The researchers expected that PSTs would develop their understanding of a science project correctly and to have a positive attitude towards a science project. The findings of this study will contribute to improving the science education program by making it more meaningful and linking it to real situations in community.

\section{Purpose of Research}

The purpose of this study was to develop PSTs understanding of a science project correctly and to have a positive attitude towards a science project. To achieve the purpose of the study, the research questions of this study ask whether or not the teaching management through service learning in "Science and Technology Project in School" course develops understanding and positive attitudes of PSTs towards a science project. And if it does, how does it accomplish these changes?

\section{Methodology}

\subsection{Research Design}

With the lens of an interpretive perspective, the research design of this study focuses on qualitative study to develop PSTs' understanding and positive attitudes towards science project in "Science and Technology Project in School" course. It involves rich description and evidence from the investigated phenomenon which the researcher has collected and interpreted from research participants and settings (Crotty, 1998). In science education, interpretive methodology is often used to understand the ways that teachers or students make sense of the social interactions both in and around schooling. It also helps teachers better understand what they do in order to improve their teaching (Gallagher, 1991). Under the interpretive paradigm, qualitative research is naturalistic in that the researchers do not attempt to manipulate or control the research setting because, in this view, the research setting is subject to change (Marshall \& Rossman, 2006).

\subsection{Research Participants}

The participants of this study are nine third-year female PSTs who are currently enrolled in "Science and Technology Project in School" course at one university in Bangkok in the first semester of 2015 who volunteered to share information concerning their science project and service learning.

\subsection{Context of the Study}

These participants were studying at a teacher education institution, which has a commitment of generating and developing PSTs of high quality and standards sufficient for high vocations. The five year program graduates teachers with the basic qualification of a bachelor's degree. In order to complete the requirements of the program, they must take the following courses: 1) a compulsory general course that includes a compulsory teaching course and a compulsory specialized disciplinary course; 2) elective specialized courses, which include a selective teaching course and an elective specialized disciplinary course; and 3) an elective course. This study was done in "Science and Technology Project in School" course which is one of the compulsory specialized disciplinary course in science teaching. This course has the value of 2 units. Researchers started teaching Science Project course from August to December 2015. The syllabus contained an induction and training period over 15 weeks (2 hours per week) explained details of what the course would involve in practice in community. The service-learning project was introduced to PSTs during the first week of course. The first half of the semester 
was spent with instruction on basic knowledge about science project. In the second half of the semester, PSTs developed and implement of their project to community. There were three projects that they initiated as 1) creating burglar alarm for community, 2) campaign about separation of garbage, and 3) examining of the quality of drinking water. At the end of semester, each group of PSTs presented their projects to expert review panels in order to critique about their projects. They most desired, thereby creating a consolidated design for eventual construction.

\subsection{Research Instruments}

There were two instruments used to gather data in this research. The instruments used for teaching management and the instrument for data collection are as follows:

1. The instruments for teaching management in this research are 12 lesson plans for 15 weeks in the "Science and Technology Project in School" course. The activities in this course are divided into 3 parts: In the first part, the fundamental knowledge of the project consists of 9 lesson plans, namely using 1 week for teaching management. Each plan is for 2 hours: 1) Rationale of science and technology project in school; 2) Type of project; 3) Components of project; 4) Basic foundation for designing project; 5) Project procedure; 6) Roles of advisor and students who are doing the project;7) Evaluation of science project; 8) Presenting and proposal of project; and 9) Teaching management in science and technology project in school. The second part of service learning consists of 2 lesson plans: 1) Using 1 week of teaching management for generating a proposal of science for the community project for 2 hours, and 2) Community service through science project and reflection with 3 weeks of teaching management. Each week is for 2 hours. For the third part, there is one lesson plan is for PSTs' reflection after community service through science project done by using 1 week of teaching management for 2 hours.

\section{The instruments for data collection}

2.1 The test of understanding in a science project consists of 9 open-ended questions about learning content in the first part about as already stated earlier.

2.2 Journal entries are instruments for PSTs to record learning outcomes. The researchers assigned PSTs to write a reflection of each class with their opinions about the science project and learning activities in each period. This includes problems and suggestions they found in each period.

2.3 Interview logs are instruments for the researchers jot down during an informal interview PSTs to clarify their experience with the science project and their attitude towards doing a science project. This is a flexible interview with adaptable questions until PSTs understood the questions in order to gain actual information. If there is a misunderstanding between the researcher and a PST, the researchers could correct it immediately.

After finishing the creation of these instruments, the researchers brought them to expert reviewers-a scientist, a science educator, and an experienced teacher. This was to validate the content in each research instrument that the researchers would apply to participants for taking into consideration the results to improve the instruments before using them.

\subsection{Data Collection}

The researchers assigned PSTs complete the test about science project before utilizing the lesson plans. The researchers organized all provided activities according to 12 lesson plans. The researchers' roles were giving consultation and suggestions for doing the science project and coordinating with organizations that led PSTs into the service learning aspect through the science project.

After each time a teaching management activity was completed, the researchers asked PSTs to record their learning as a journal entry in order to reflect their acquisition of knowledge learning activities. PSTs submitted their journal entries to the researchers at the next class. When completing the teaching management, the researchers asked PSTs to complete test about science project again.

Furthermore, the researcher did an additional interview with PSTs about responding to questions in the measurement of accomplished activity ideas that needed further clarification. Each data source is required to be combined with different data sources in order to enhance validity and cross-checking of the findings via triangulation (Patton, 2002). In this research, the researchers used pseudonyms.

\subsection{Data Analysis}

Researchers analyzed all collected data by a triangulation strategy to ensure the trustworthiness from reading and summarized the PSTs' answers in the test about science project, interview logs and journal entries of the PSTs. Researchers sorted data of each PST and categorized in a group. The information of each group was compared 
and contrasted as to the differences and similarities among them in order to summarize data about the development of PSTs' understanding and attitude towards a science project. The researchers also used descriptive statistics to identify which categories were most commonly answered by PSTs.

After completion of data analysis, details about the data collection, coding, and analysis were examined and reviewed by experts in science education, who gave the researcher feedback on the accuracy of the process. In addition, the researchers also allowed the participants within the study to review and verify that the information is a correct interpretation. To protect PSTs' identities and privacy, the researchers used pseudonyms to represent PSTs as A01 mean PST number 1.

\section{Findings}

Researchers found that the teaching management through service learning could develop PSTs' understanding and attitude towards a science project. Researchers presented 2 results: 1 ) the understanding of PSTs in doing a science project, and 2) the attitude of PSTs towards a science project, both of which are presented below.

\subsection{The Understanding of PSTs on Science Project}

1. PSTs changed their understanding that a science project is related only to science to understanding that a science project is related to interdisciplinary fields and science.

In the first hour of teaching management, researchers assigned PSTs to do an activity for expressing their knowledge about a science project. In regard to the first lesson plan, questions were open-ended in that they asked PSTs' opinion about meaning, experience, the essence of a project, etc. When PSTs answered these questions this formed the activity plan culminating into a discussion. As each PST shared their experiences and opinions, researcher found that 7 PSTs (78\%) thought that a science project includes specific questions to discover new knowledge and innovation through only scientific procedure with guidance from a teacher as one of them shared idea that "A science project is taking science knowledge into a project through a scientific procedure." (A03, Pretest of understanding in a science project). Consequently, another of them stated in classroom that "Before studying this course, I was doing a project in a middle school and thought that doing a science project is using a science procedure to find answers in regard to the research topic. Sometimes, it was an innovation by using only a science principle." (A08, Classroom observation of the first period from August 20, 2015).

From doing project activities through service learning, 9 PSTs (100\%) illustrated that a science project is not only using a science procedure but also an integration of science with other disciplines, for instance, multidisciplinary fields in mathematics, arts, technology, and sociology. For example, one of them mentioned that "This is the way to bring science knowledge we have and apply it with technology for a new innovation that benefits daily life and the future." (A02, journal entry from November 5, 2015). In another relevant opinion, another of them expressed that "Before doing the project, I thought it was for solving problems by using science principles but after doing the project by myself, in addition to the project training it helped me to solve other problems as well. It enabled me to solve social problems. For instance, I can use this project experience in a similar way as my classmate who is working on an anti-theft signal. Working in a science project, doesn't only use science procedure skills in learning to solve problems but applies to other areas because it is an integrating of various subjects, and it can be part of any subject that allows learners to be able to practice by themselves." (A07, Classroom observation from November 26, 2015).

2. PSTs changed their understanding that students' roles in a science project are to follow their teachers' assignment of tasks to them. Rather students can do a science project that is in accordance with their own interests and communities.

According to data collection, the researchers discovered that the answers about students' roles during the first part of teaching management showed that 8 PSTs $(89 \%)$ understanding was that students do a project by following teachers' guidance only, as one of them explained that "I had done a science project during secondary school. It was required for students in a science program but the teachers selected the topic that we had to for a competition." (A02, Pretest of understanding in a science project). Similarly, one PST expressed in classroom that "My experience in doing a project was that my school put this up as one subject for studying once a week. There was a teacher, acting as advisor, who told us what we were going to do during an early stage and later on it became a free choice period." (A07, Classroom observation from August 27, 2015). In addition, another of them revealed that "Sometimes, I could not come up with the topic, so I used the provided topic of the teacher." (A05, Journal entry from July 4, 2015).

When PSTs did a project and experienced learning activity, 7 PSTs (78\%) changed their mind about students' 
roles as working on a project by following students' and community interests as cited by A05 and A04 below: A05 described: "Students will have an important role in selecting a topic that they want to do. They can search for something that arouses their own personal interest or is a community problem, and students, thus, decide on their topic by themselves." (A05, Journal entry from October 1, 2015). A04 also added: "As when being a student teacher tell them an answer, it means teachers scope out what students' think. While teachers do not tell them any answers and raise more questions when students have problems, it means using questions as guidance. Students have to find answers, doing more research and finding the solutions eventually." (A04, Journal entry from October 1, 2015).

Moreover, 8 PSTs (89\%) in studying a science project also learned about doing the project and then they gained understanding about student roles through hands-on experiences while they did the project as students. Hopefully, if they were to become an advisor of a project in the future, they might understand students' roles. For example, the journal entry of one PST explained: "When I can't think of any topic, I expect my teacher will tell me the potential topics. But the teacher told me to search for additional information, asked me about my interests during a conversation with me until I discerned my own topic for doing the project. So, I understood students' need for a teacher's help on what the issues are, and if I was an advisor, how I should give advice to my students without determining the topic for students." (A02, Journal entry from October 8, 2015).

3. PSTs changed their understanding from an advisor's role for a science project that only gives consultation about the procedure of doing a science project to that of an encourager for students to discover and do their project according to their interests.

For teacher' roles, 7 PSTs (78\%) have an idea that teachers are an advisor who gives advice only. But after completion of a project, they found that teachers not only give advice and suggestions but also assist students for seeking equipment, inviting an expert from other fields to participate and arranging for a venue as stated by PSTs that "At first, I thought the teacher is only giving advice about the current project. But while doing it and encountering problems, the teacher will give advice that includes how to introduce an expert contributor or participant, the way to write a letter that communicates with organizations, and how to engage inappropriate conversations with each. In addition, teachers help to find the solutions in every circumstance." (A05, test of understanding in a science project), and "Earlier, I didn't think that an advisor would assist me on how to contact an expert who would be able to help me." (A09, test of understanding in a science project). Similarly, some of them reconceived their ideas that being an advisor meant having to know everything while teaching students as presented by one PST that: "I thought teachers have to know everything before they can give students advice. Thus, if I am a physics teacher, I cannot give good advice to students who are doing biology or chemistry projects." (A03, Classroom observation from August 27, 2015).

However after doing service learning, 9 PSTs (100\%) have changed their understandings about their previous ideas as one PST pointed: "For doing our project, I can relate that my group is doing a biology project but my advisor is from physics. Thus, I learned that an advisor does not have to know everything. Teachers and students can find the answer together. Teachers can introduce a subject area expert to students. Therefore, I am confident that in the future although I don't know biology or chemistry, I can give good advice to my students." (A03, Informal interview from December 3, 2015).

Moreover, researchers found that 6 PSTs (67\%) have seen that another important role of a teacher is giving morale support to students. One PST addressed this: "When I do a project, I have seen teachers encourage students verbally, and that is important. As there are many problems while running a test, there are mistakes requiring redoing it 4-5 times. When I have a conversation with an advisor, she/he gives me morale support. This makes my energy recharge and I can continue doing a project until I succeed. So, I think giving morale support is one of the important roles of an advisor." (A01, Posttest of understanding in a science project).

\subsection{The Attitude of PSTs towards Science Project}

For discerning a student's attitude before teaching and learning management begins, researcher asked PSTs' opinion on whether they like to do a science project or not? And why? From the classroom discussion, there is only one PST (11\%) who affirmed he liked it but not that much. The overwhelming opinion of the remaining 8 PSTs $(89 \%)$ in the participants responded they did not like to do a science project and gave the following reasons such as 1) time consumption as: "There is a limited time for doing. I cannot do research or analyze problems completely. It makes me feels that the project is always lacking." (A01, Classroom observation of the first period from August 20, 2015), and "Time consumption in doing, insufficient time because there are several steps and many processes for doing one project." (A09, Classroom observation of the first period from August 20, 2015), 2) lack of prior knowledge about doing science project as "It is difficult to come up with a problem. I don't know 
what the project is that I should do."(A04, Classroom observation of the first period from August 20, 2015), and 3) Bias about project advisor as "It is a bias that comes from doing a project during high school. The preferable topic is not approved by advisor. An advisor usually assigned a topic of a project for students. It is not fun to do." (A03, Classroom observation of the first period from August 20, 2015).

However after PSTs have studied about the project through service learning, they acquire a better attitude in 3 aspects as shown in table 1 below:

Table 1. PSTs' Attitude towards Science Project

\begin{tabular}{lc}
\hline \multicolumn{1}{c}{ Attitude of towards Science Project } & Frequency (Percentage) \\
\hline 1. Developing a science procedure skill and life skill & $9(100)$ \\
2. Acquiring new knowledge by doing research & $7(78)$ \\
3. Doing a useful thing for the community & $3(34)$ \\
\hline
\end{tabular}

For in-depth detail of each aspect, the researchers would like to present as in the following paragraphs:

1. A science project though service learning can develop various skills.

From doing a science project though service learning, 9 PSTs (100\%) develops a science procedure skill and life skill through the work involved. PSTs can decide carefully for solving problems, analyzing and categorizing information, communicating effectively, and building good relationships with a community. For instances, the interview data of PSTs described: "At first, I wanted to take a picture, but the senior student told me very strictly that I cannot take a picture. My friends and I consulted together and decided to talk with the senior student to explain that we are not going to distribute this picture, but we are going to use it for teaching and learning only. Finally, the senior student gave us permission. I realized then that decision making is the important thing for solving the problem, but it must include using appropriate persuasive words and right timing." (A08, Informal interview from December 17, 2015), and "Working trained us to solve the problem by using a science process and building self-confidence to express and talk with others in the community." (A09, Informal interview from December 17, 2015).

2. Doing a science project through service learning makes PSTs gain new knowledge by themselves.

When PSTs do a science project though service learning, 7 PSTs (78\%) acquire new knowledge by doing research, solving problems during discovering and working through project tasks. They build their understanding and enjoy learning new things by themselves. For example, A04 and A01 reported: "In doing this project, I engaged in a new experience in learning and found new knowledge by myself. I am excited and happy." (A04: Journal entries from November 19, 2015)., and "Working the project allows me to get new knowledge that I have never known before." A06 reflected the relevance of experience: "I have fun searching for an answer and solving problems. While working, there are new problems, always. We have to think how to solve the problems for finding answers. We have to do research, and I found that research has the kind of knowledge that I had never known before. If I did not do this project, I still would not know about this." (A01: Journal entries from November 26, 2015).

\section{A science project through service learning benefits society.}

To do a science project though service learning, 3 PSTs (34\%) feel they are doing a useful thing for the community. They can use their knowledge from learning to apply benefits towards solving social problems, i.e. the interview with PSTs as: "Before doing the project, I thought it is enough for solving problems to use science principles. After doing the project by myself, I found that the project trained me in solving problems, and I can use the project to solve social problems too. It is similar in approach as my friend who did an anti-theft signal." (A07, Informal interview from October 22, 2015), "At the beginning, I thought garbage is the problem that is generally easy to be found. After doing the project, I see the actual situation that made me know that it is a huge problem. If everyone is not helping to solve this together, this problem will increase more and more. In the project, I introduced knowledge about the categorizing of trash. Though this is a small initial step, I am proud of helping others realize the importance of sorting garbage more." (A03, Informal interview from November 19, 2015), and "Earlier in the project, the result showed that water is contaminated, I thought I already got the result successfully and the project was already done. But the advisor said to me, "Why do you not do more to solve the problem? So I reported the problem to the administrative officer in order that the problem be known and the solution be found. I feel happy that our project influences society. Thus, I think a science project can 
apply in real life to solve the problem and attain societal benefits." (A03, Informal interview from December 3, 2015).

\section{Conclusion and Discussion}

Teaching management through service learning is primarily featured in "the Science and Technology Project in School" course. Researcher found that PSTs understanding increased greatly in a science project. Earlier, they understood that a science project is about science subject only but through working the course they experienced the realization that a science project requires integration with other disciplines. Supinanon (2009) stated the relevance of doing a project through service learning, namely students can serve the community and as learning is not an isolated subject it integrates holistically with other fields.

In addition, PSTs have changed their understanding of student roles is doing a science project by readjusting their thinking that teachers alone determined the topic and work of the project. Their understanding transformed into a science project selected and accomplished from their own and community interests as mentioned by Taylor and Ballengee-Morris (2004)in that teaching management through service learning opens an opportunity to students to learn and self-develop while participating in service learning as needed by a community.

PSTs in this study have changed their understanding that an advisor of a science project has the single role to give advice about the process of doing a science project. In fact, an advisor's role is also giving morale support to students while doing a science project. This is in accordance with Lin et al. (2013) who addressed that learning atmosphere through service learning emphasized the interaction between students as a colleague and with people in the community as a support environment.

For attitude towards a project, PSTs developed a positive attitude towards a science project. They have identified that a science project makes them gain new knowledge by themselves including other skills that benefit society which is relevant to Prentice \& Garcia (2000) who pointed out that students who are learning though teaching management will gain direct experiences for their future professional teaching careers and are also able to develop their own self-concepts of themselves as learners in addition to acquiring academic knowledge.

\section{Recommendations}

The findings showed that teaching management through service learning can develop understanding and attitude towards a science project. As a result, researcher suggests the instructor who is in charge of this teaching management of PSTs and related staff should guide service learning as part of teaching management as a subject in relation to a science project. However, teaching management through service learning has time constraints. For this reason, the instructor should suggest PSTs contact organizations to observe problems for doing the science project at the beginning of teaching management. For future research suggestions, researcher should find an effective practical way of teaching management through a science project that is appropriate to develop understanding and attitude in a science project of PSTs through service learning. In addition, researcher should follow the application and further use of knowledge in a science project of PSTs in teaching management for students in actual classes.

\section{References}

Blumenfeld, P., Soloway, E., Marx, R., Krajcik,. J., Guzdial, M. \& Palincsar A. (1991). Motivating project-based learning: Sustaining the ding, supporting the learning. Educational Psychologist, 26(3-4), 369-398.http://dx.doi.org/10.1080/00461520.1991.9653139.

Buck Institute for Education. (1999). PBL Overview. http://bie.org/stw/index.html

Crotty, M. (1998). The Foundations of Social Research: Meaning and Perspective in the Research Process (1st ed.). Australia: Allen \& Unwin.

Dosch. L. (1998). Lynn's Learning Pages. Retrieved from http://www.inform.ns.k12. mn.us/\%7eldosch2/ $\mathrm{pbl} / \mathrm{pblexamples/}$

Gallagher, J. J. (1991). Uses of interpretive research in science education. In J. J. Gallagher. (ed.). Interpretive Research in Science Education (pp.3-17). NARST Monograph. Number 4. Manhattan, KS: Kansas State University.

Lin, C. Y., Wu, S. W.,Wu, S. F., Pan, B. S., \& Liao, H. C. (2013). Effect of service learning in University in Taiwan. Social and Behavioral Sciences, 116(2014), 902-906. http://dx.doi.org/10.1016/j.sbspro. 2014.01. 317.

Marshall, C., \& Rossman G. B. 2006. Designing Qualitative Research (4th ed.). California: Sage Publications. 
O’Grady, C. (2000). Integrating Service Learning and Multicultural Education in Colleges and Universities. NJ. Lawrence Erlbaum: Mahwah.

Office of the National Education Commission (ONEC). (2003). National Education Act B.E. 2542 (1999) and Amendments (Second National Education Act B.E. 2545 (2002). Bangkok: Pimdeekanpim Co., Ltd.

Partnership for 21st Century Skills. (2009). P21 Framework Definitions. Retrieved from http://www.p21.org/storage/documents/P21-Framework -Definitions.pdf

Prentice, M., \& Garcia, R. M. (2000). Service Learning: The next generation in education. Journal of Research and Practice, 24, 19-26. http://dx.doi.org/10.1080/106689200264321.

Supinanon, P. (2009). Teaching Pattern of Service learning. Retrieved from http://www.oknation.net/ blog/learning/2009/01/29/entry-1

Taylor, P., \& Ballengee-Morris, C. (2004). Service-learning: A language of we. Art Education, 57(5), 6-12. http://dx.doi.org/ 10.1080/00043125.2004.11653561

The Institute for Promotion of Teaching Science and Technology (IPST). (2008). The Manual of Science Learning Management under the Basic Education Curriculum B.E. 2551. Bangkok: Karusapa Press.

\section{Copyrights}

Copyright for this article is retained by the author(s), with first publication rights granted to the journal.

This is an open-access article distributed under the terms and conditions of the Creative Commons Attribution license (http://creativecommons.org/licenses/by/4.0/). 